\begin{tabular}{|l|l|r|}
\hline Volume 1, Number 2 & Example Case Study & 1 MAY 2017 \\
\hline
\end{tabular}

\title{
Case Study: How I Finished my DBA in 2 Years... Almost!
}

By

Rob Hammond

T here is no one best course through a Doctorate of Business Administration program but there are paths that maximize your time and value. Some people will wander through the research wilderness until having an epiphany, while others will treat the program like a journey-man and "do the work", and still others will panic at the end of the third semester and "have to pick a topic for the dissertation". If you enter the program with even a general idea of your research interest, then there is a different approach.

Rob Hammond is a member of the inaugural cohort of the Muma College of Business DBA program at the University of South Florida. For almost 30 years he has worked in and around sales, marketing and product in large corpora- tions. Rob witnessed enormous waste in sales training and thought it could be done differently. This was his topic of interest. Rob also had an idea from his experiences of what might be causing the issue.

About half way through the first semester, Rob was picking the next paper topic and decided that he would adopt the strategy that he would try to find a way to advance his understanding of his research area in every class. This strategy became the navigation beacon for his DBA journey. This case is documenting this strategy along with a collection of his experiences from the DBA program for the readers in hopes that it may provide future students a few more restful nights as they begin their own academic journeys.

Keywords: Executive Education, DBA, Executive Learning, Active Learner, Life-long Learner

Copyright $\odot$ 2017, Rob Hammond. This article is published under a Creative Commons BY-NC license. Permission is granted to copy and distribute this article for non-commercial purposes, in both printed and electronic formats 


\section{Introduction}

"Uhhhhh, What am I going to do?" thought Rob. "Tomorrow is the next sales training class. If I don't do a survey now, I'll miss the opportunity to get survey data from before training. And what about IRB? That's definitely not going to happen tonight."

Rob Hammond was an inaugural cohort member of the Muma College of Business Doctor of Business Administration program at the University of South Florida (see Exhibit 1). Rob was similar to many in the cohort with 30 years of work experience and a desire to finish his education with a terminal degree, but no rational economic trade-off to forego a career in marketing and sales for a traditional Ph.D. program. Every year or so, since he had finished his MBA 20 years ago, Rob would search around and see if there was a way to make obtaining a doctorate rationally possible. Finally, in the fall of 2014, Rob stumbled across videos that announced the Doctor of Business Administration program at the University of South Florida (see Exhibit 2).

It was now the summer after the first semester. The program began in January, so Rob had finished four courses which included material on research methods, research writing and case research. The courses combined to challenge students to develop research questions and introduced research methodologies including quantitative research with surveys (see Exhibit 8). Rob had entered the program with a fairly developed area of interest and even a potential model for how to think differently about sales training. This study area was also related to Rob's work at a global cloud service provider.

Returning to Rob's quandary about whether to seize the opportunity of surveying sales people, Rob's company was rolling out a new training program and Rob was helping facilitate the class by being the customer in role play training scenarios. Rob thought, "This is just too good to pass up. I've got to try. Worse case, I throw it away and write it up for my dissertation as a "leaning event". But what about IRB and doing the survey incorrectly?" Rob checked his notes to confirm what he remembered. IRB wasn't a problem if the research was something you would do for work anyway. Certainly, checking on the effectiveness of training was something the company should do. Then again Rob couldn't recall anytime over the past 30 years when a company had actually done before and after surveys. As for doing the surveys incorrectly, Rob had just finished a semester of work and had good examples of the types of questions he wanted to ask. Rob had also been running an expert panel to develop problem statements, so there was a rich set of data to draw upon for the questions.

Rob went to his desk, got out his books and notes, and proceeded to edit the questions he had developed for the class into a one page survey. In the morning Rob administered the survey to the sales people at his company and got his first data set. That evening he created a second survey with many of the same questions and then asked the sales people to complete the second survey at the conclusion of the training. "Well, now I'm committed," thought Rob (see Exhibit 6).

The remainder of this case chronicles Rob's efforts through the first two years of the DBA program. In the first two years of the DBA program, Rob submitted four papers for publication and completed a draft of a practice inspired book. Lessons learned, best practices and his approach for combining research, work and scholarly enrichment are shared with the hope that these experiences can provide guidance for students and faculty seeking to maximize and enhance the DBA journey.

\section{The Case}

\section{Background}

Rob Hammond was part of the first cohort of the Muma College of Business Doctor of Business Administration (DBA) program at the University of South Florida. Rob had worked primarily at large technology companies in sales, marketing and product for over 30 years. While the duration of Rob's work experience was similar to the rest of the cohort, Rob's background was also distinctive in that his work included writing creatively, a lot. Another difference was that Rob had earned both a MBA degree and a Masters of Engineering degree. Rob's engineering master's thesis relied heavily on probability, statistics and computer programing. Not surprisingly Rob was comfortable with math and statistics specifically.

Rob also came into the DBA program with a fairly developed idea of what he wanted to research. His belief was that companies who experienced major business disruptions (mergers, acquisitions, technology change or competitor action) were attempting to transform their sales teams incorrectly. As a result, good people were losing their jobs and companies were wasting literally billions. Over the years, Rob had observed that companies would fail in their attempts to transform the sales organization and in the end replace a majority of the sales force with new resources. The process played out like an old trite movie script. Disruption occurs, business 
results suffer, hire consultant(s), train sales force, results don't improve, replace sales people. It was pure insanity. How did sales people who were one year highly effective and well paid become so incompetent the next year that they needed to be replaced? From his experience as a sales person, sales manager and business executive, Rob knew sales people were more than order takers and there had to be more to understand about the process. Rob had also observed that there were distinct sales behavior types and that it was fairly easy to determine which sales type a sales person was by just talking to them. Rob's thought was that it would save sales jobs, and companies a lot of money, if it were possible to be more effective in transforming the selling behaviors of sales people by differentiating the training based on the seller's behavior type and likelihood to change.

\section{Chronology}

Exhibit 3 and 4 list the curriculum associated with the Doctorate of Business Administration. Exhibit 3 is the curriculum as listed in the program guide and Exhibit 4 lists the courses that were taught in sequence during the first two years of the inaugural cohort. Reference num-

bers have been added to Exhibit 4 to aid the summary of events that follows. Exhibit 5 provides a chronology of Rob's activities in the DBA program associated with the reference numbers in Exhibit 4.

In the initial research methods course (see Exhibit 4, reference 1) Rob wrestled with writing research questions that could be tested and also got to the heart of his question about transforming sales people. Rob's initial thought was that the selling type was related to personality. Was it possible to use something like personality tests or LinkedIn connections to suggest a person's selling type? Through the course, Rob explored different concepts and received directional feedback from the faculty. The second course, being taught at the same time, was Informing Science (see Exhibit 4, reference 2). In this course, Rob was exposed to a number of academic theories including: Informing Science, Complexity and Innovation Diffusion. These academic theories clicked for Rob. In combination, these theories could explain why some people changed behaviors over time as opposed to all at once.

Then, in the second half of the first semester, the program called for writing a discussion case. The professor leading the course was Dr. T. Grandon Gill, the DBA Academic Program Director. Grandon encouraged the cohort to write about a business problem that the students knew well. Rob chose to write a case about a business disruption and making a choice on how to train sales people. While not a research hypothesis article, the discussion case (see Exhibit 4, reference 4) established the business context for the research that was to come. The discussion case was later published in the Muma Case Review as part of the second publication course (http://mumacasereview.org/). Research Writing was the other course during the second half of the first semester (see Exhibit 4, reference 3). This course focused on helping the cohort narrow down research topics to something that could be executed within the structure of an article.

In the summer, after the first semester (see Exhibit 4, reference 5), Rob was energized. Academic theories provided the basis for a new understanding of a vexing problem and new skills had been introduced for research. Rob used the summer break to work with experts to develop a more complete understanding of the sales transformation process and expose his own blind spots. Then, just before the start of the second semester, Rob was involved in sales training first as a participant, then as a facilitator. The training happened quickly and there was no time to talk with faculty about the training, research or surveys. Rob decided to go ahead and develop a survey that could be administered before and after the training. The goal would be to determine if there was a change in the seller's beliefs about how to sell after the training. General demographic information was also captured as part of the survey to investigate various independent variables. The first step was to determine what type of scale to use. Rob remembered from class that a 5-point scale was acceptable. He then went to Google Scholar and researched scales to make sure there was research on whether to use a 5 or 7-point scale. Rob found an article that explained that there was no statistical reason for a 7 point scale (Hinkin, 1998). Done. The surveys were written with a 5-point scale.

Rob reviewed the survey and results with Grandon Gill and Matt Mullarkey, DBA Program Director during the September residency. Grandon and Matt provided guidance on additional steps that should be taken, like reviewing the questions with the expert panel individually and then together. Rob conducted these reviews and then had the opportunity to deliver the survey two additional times with other sales resources. The process, timeline and activities associated with developing the survey are noted in Exhibits 2 and 3.

In parallel, Rob was also researching Innovation Diffusion. It seemed likely that there were studies that 
had already been conducted on Innovation Diffusion. Not surprisingly, a literature search turned up little for Innovation Diffusion in sales beyond the adoption of sales force automation (SFA) software applications. However, Rob was able to find a validated survey including the survey instrument that determined the likelihood a worker would adopt a work station. Rob modified the questions to reflect his area of study and then used this survey with the later sales training groups. Rob now had two surveys with actual data. The process and activities associated with adapting a pre-existing survey are noted in Exhibit 4.

The first statistics course, Linear Statistics (see Exhibit 4, reference 6), was being taught while the sales training was being conducted and the final project in the Linear Statistics class was to clean a data sample and conduct a number of statistical methods. At Matt's suggestion, Rob approached the professor about using his survey data instead of the provided data sample. The professor was more than supportive. Rob met with the professor one-on-one several times to complete the analysis and developed deeper and deeper understanding of the data from each interaction. The second half of the semester included the second statistics course, Multi-variate (see Exhibit 4, reference 8). Again, this course included an end of course project. Rob used his own data again, this time conducting factor analysis and cluster analysis of the data.

Innovation and creativity (see Exhibit 4, reference 7) was the next course delivered during the fall semester of the first year. Rob's background in product and marketing provided a wealth of information for him to draw upon for the course. What Rob did not expect was developing self-awareness of his own creativity. One of the papers that was reviewed in the course discussed managing "creatives." The paper listed a number of traits that were found in creatives. When Rob asked his family and co-workers if they thought he was a one of these "creatives", the reactions were incredulous, "ya think?" and "duh" were two of the common responses. Self-discovery was not listed in the course catalogue or learning outcomes for the course, but nonetheless informing occurred.

The second publication course (see Exhibit 4, reference 9) provided an opportunity to package the research and statistical analysis to complete a second paper. "Today, I Fired my Salesforce" has been submitted to the Muma Business Review (http://mumabusinessreview.org/) (see Exhibit 7).

After the statistics courses, demonstrating that a salesforce was a complex landscape, finding evidence of different sales types and innovation diffusion types, the next frontier was to develop a better understanding of the inputs and mechanisms associated with the sales process. The next course in the program, Qualitative Methods (see Exhibit 4, reference 10), provided the perfect vehicle for the next investigation. Rob developed questions and leveraged his background in focus groups from product and marketing to conduct an initial set of interviews of both sales people and sales managers. The interviews were coded and then a model was developed. A paper, "Salespeople, how do you change them if you can't train them?" was written and expected to be submitted to an academic journal. Exhibit 9 lists the process flow associated with the qualitative grounded theory research. Exhibit 10 lists the dates of the various activities and Exhibit 11 is an excerpt of the coding that was derived from the process. The grounded theory research followed the process identified in the Qualitative Inquiry and Research Design course: choosing among five approaches initiates the process of conducting a qualitative study (Creswell, 2012).

Commensurate with the qualitative methods course was the Law, Ethics and Sustainability course (see Exhibit 4, reference 11). Rob had made a commitment to himself that he was going to find a way to make every course contribute to his research. Sure, there are lots of law and ethics problems for sales, but that is known and not very interesting. Sustainability was a different thought. Like most courses the Sustainability course included a paper. Rob chose to adapt Sustainability with its three domains: social, economic and environment as a way to describe the cost of replacing sales people. The resulting paper has been submitted to the Muma Business Review (http://mumabusinessreview.org/).

The third publication course was next (see Exhibit 4 , reference 12) and this course provided another opportunity to refine prior work. Rob had learned something about the program structure by this time. He had used the template for the Muma Business Review for his final project in the qualitative methods class, so now he could just edit the paper for the publications course. Genius.

Since reading the dissertation requirements at the start of the program, Rob had long planned on writing a book as his dissertation project. With a discussion case completed, two quantitative research projects, a qualitative research project and three papers done, Rob began spending more time thinking about his dissertation project. The final statistics course 
was Business Analytics (see Exhibit 4, reference 13). For this course, Rob used the final project to write a section of the dissertation project, "Managing Sales with Analytics".

The qualifying examination for the DBA program was straightforward (see Exhibit 4, reference 14). Rob used the charts and material from the various papers and was able to develop a narrative explaining the alignment of the various research efforts into a cohesive body of work.

Rather than taking the summer month (see Exhibit 4 , reference 15) off, Rob used the time to develop online surveys. The survey software Qualtrics is provided to USF students at no additional charge. The software was intuitive and it was straightforward for Rob to convert the paper surveys (sales type and innovation diffusion) into on-line surveys that could be sent out in email or posted online. Adding online surveys was an important step to obtain more responses in support of statistical rigor and generalizing to different groups. To obtain responses, Rob contacted the first and second DBA cohorts, co-workers who had not be previously surveyed, vendors, trade-show contacts along with posting the surveys on Twitter, Linke-

dIn and finally sending all first level connections in LinkedIn with sales in LinkedIn title a personalized InMail. Based on the timeframes each channel was executed, Rob believed the Linke-

dIn personalized InMails

were the most productive response channel. Statistical analysis of the two surveys was also completed during the summer along with updating the Literature Summary to reflect the varied articles used in the papers and other supporting materials. The Literature Summary was valuable in tracking where the articles were used and as a simple way to reference particular articles. The categories used in Rob's Literature Summary were: Type, Topic, Findings, Citing, Summary, Impact and Application to Research (see Exhibit 12). In total Rob had recorded around 100 articles in his Literature Summary over the course of the two years of research.

Rob reviewed his research efforts with Dr. T. Grandon Gill during the first residency of the fourth semester. Dr. Gill provided two challenges to Rob. The first challenge was to think about how he was going to explain his research to the dissertation committee and the second was that given Rob's plan was to write a practice and academic informed book--how to make the book more than an assignment and think about ways to make it a market success.

Keeping with the strategy of always finding a way to leverage the coursework to advance the research,
Rob used the concept mapping assignment from the Strategy course (see Exhibit 1, reference 16) to map the grounded theory model developed from the Qualitative Methods course to theory. This effort codified the linkage of the research with academic theories. Coincident with the Strategy course was a course investigating strategic climates (see Exhibit 4, reference 17). For the strategic climate course, Rob used the readings on climate embedding techniques in evidence based healthcare to develop a model for how to embed new selling behaviors in sales. The final paper for the course evolved into part of the dissertation project.

Exhibit 4, reference 18 identifies the final course of the first two years. This course explored the prospects of teaching in an academic setting. Part of the coursework was to create a course on a particular topic including teaching methods, syllabus and associated course material. Rob chose to develop a course on sales.

The final two references in Exhibit 1 expand on the efforts listed in Exhibit 4, references 1 through 18. Exhibit 4, references 19 and 20 represent continued work on the dissertation project.

At the time Rob began the DBA program, Rob was leading a global product organization with resources around the globe. During the first two years of the DBA program, Rob changed jobs to a sales leadership role focused on helping the sales resources sell new products. Then, a year later, Rob used his new research knowledge and growing passion for sales training to become head of sales operations and inside sales. Rob was heard to explain that it was as if he was working in a lab. The convergence of research and practice fed each other in ever expanding and deepening understanding.

\section{The Results}

The Doctorate of Business Administration program at the University of South Florida is a 72 hour program. As such, it takes three years to complete. While Rob couldn't technically finish the DBA in two years, his efforts established a substantial body of work that included four papers and the first draft of a book. After some conversation with his dissertation committee, the committee approved his dissertation proposal and Rob finished the first draft of his book. Beyond the research and intrinsic rewards of reducing stress, the process Rob used in the program produced practice centered work that was applied in his workplace and influenced others. The next step for Rob was clear--work with his dissertation committee and leverage the university's assets to develop 
an interesting, marketable book and share his findings with practice.

\section{Discussion}

Rob's approach to the DBA research was unique in the cohort.

While Rob's path through the DBA may seem to be a straight line, the reality is that Rob had to pivot his efforts multiple times. One notable example of adjusting course was when Rob had trained all of the sales resources. As a result, there were no more before and after training surveys to do. Rob wrote his paper and moved on to other questions about the population. Essentially, each class was a pivot to another facet of the broad topic area of sales transformation.

Rob's approach to the DBA program (1) capitalized on his access to people and data, (2) was grounded in a practice-inspired problem where Rob believed he had unique insights based upon years of experience in the domain, (3) utilized every course to advance his exploration of the core phenomenon of interest, and (4) constantly pursued collaboration with professors and fellow students in the conduct of the research methods. In a unique sense, he found a way for each course and each paper to build upon each other in the exploration of his area of inquiry. Rob also found gratification in sharing what he had learned in various outlets including his own company, publications, conferences and with other sales leaders directly and via social media.

Dr. Matt Mullarkey, DBA program director commented, "Rob found a way to maximize the opportunity presented by every course and every publication activity to advance his research. He was never afraid to experiment and to use the research methods he was learning to explore the topic. His singular purpose facilitated his relatively streamlined approach to his dissertation. Not all DBA participants will be so fortunate. At times, an experiment or exploratory research activity will lead to a dead-end and the DBA participant will need a fresh approach. Nonetheless, the path and approach Rob took is a repeatable approach all DBAers would be wise to consider." For Rob, personally, the approach was simply a logical progression of inquiry. When a tool was presented, he applied it to the research. This approach yielded benefits in Rob's work as he moved into a planning leadership role and applied his research. Areas in practice that were impacted by the research included sales training, sales person hiring and sales operations.

\section{Suggestions}

When asked for suggestions on how to navigate the program, Rob provided the following list of suggestions and explanations. Table 1 provides a summary of the topics and examples in each category.

\section{Be Real About Time}

The DBA curriculum is rigorous and takes a significant commitment. It is critical to identify a time when a student can think critically. This needs to be separate from the day's task demands. For Rob this was a daily run each morning. Rob would pick a topic, research, paper structure, assignment or work topic and only focus on that topic for the day's run. When he finished he would record his new insights. Make time to think. The second time topic is to make time to work and recognize something is going to have to give to make time for research, analysis, writing and coursework. Two things Rob did were: first he almost stopped watching TV entirely and second he stopped going out for lunch during the week.

\section{Topic Selection}

It's unlikely that a student will know exactly the research question when the program begins. Even selecting the topic area pays dividends as research builds and familiarity with authors, methods and existing research grows. Another efficiency item is to select a topic related to work. In Rob's case, it was difficult to separate his research interests and work interests. As such, there was great leverage and cross contribution. The third and perhaps most important consideration is to pick a topic that is interesting to the student. Three years is a long time to spend with a topic that is not interesting.

\section{Be Creative}

Ideate with paper and pen--it simply works better. Also, pick a tool for capturing thoughts when they occur. For Rob it was using the note function on his cell phone. Pen and paper would work along with the voice memo function of the phone. The key is for the tool to be pervasively accessible.

\section{Plan}

The DBA curriculum at the Muma College of Business, University of South Florida is designed to create opportunities for students to use subsequent publication courses to publish research performed in in prior courses. A key time saving technique is to use the publication template when writing the research paper. The student then turns in this paper for the research class and later embellishes the same paper for the publications course. Essentially, the student is able to double the amount of time available to do 
research and write. Rob's approach of finding a way to leverage every class for his research, created new and unexpected perspectives. By self-imposing the constraint, Rob forced himself to change perspective and develop new insights into the research.

\section{Get Work Done}

When it's time to write, write. Each publication course incorporates peer reviews in the Muma College of Business DBA program. A student will benefit from both providing and receiving feedback in the peer review process. Providing peers more complete input ensures more constructive feedback and improves quality.

Turning work in late creates increased work load as new assignments stack on top of late work. In addition, many of the courses build on prior work creating an unstable foundation for future learning. Resist the temptation to put the DBA program aside for a month during the breaks. The breaks are ideal times to work ahead to complete reading, conduct research, update the literature summary, finish a statistical analysis or complete a publication. In truth, the DBA program is more than six semesters; it is three continuous years.

\section{Use the Tools}

Even though professors will use different tools for statistical analysis, pick one and use it to the extent possible. Most professors will provide print outs for the problem sets, so that a student does not

have to learn another tool. Rob found JASP and Radiant to be effective and easy to use. Rob found using the projects in the statistics classes to conduct statistical analysis of research to be an effective use of time and he was able to benefit from the availability of faculty as well.

Rob recommended using cloud storage like Microsoft OneDrive or Dropbox to store incremental versions of files including research data and charts. As the DBA program evolved, Rob found that he needed to go back to earlier draft versions of papers as well as revisit research. Fortunately, Rob was in the habit of saving major versions of papers and each stage of data analysis. For data Rob suggested saving the raw data untouched, then cleaned, then with any calculations, and then finally as a comma separated (.CSV) file version that could be imported into the statistics package.

Rob also found organization of the files to be very important. Rob's habit was to put the date of each major working version in the title of the file as YYMMDD. For instance, 160915 would be September 15, 2016 and the file name would be something like "Hammond Novel Idea Sales 160915." To help find the various papers and data files, Rob suggested creating a folder for each class on cloud storage. Rob used OneDrive and found the integration with the DBA program provided Microsoft tablet computer convenient. Storing the files in the cloud also provided added security in case the tablet failed or if he was working on another computer. Rob also configured his Endnote storage in the cloud for the same reasons.

\section{Stay Current}

In addition to finishing assignments and keeping up with the program it is helpful to update the literature summary as the student moves through the program. Keeping the literature summary current will improve the clarity of the findings and impact to research as well as avoid having to retrace steps in an attempt so find "that one critical article." Another helpful routine is to add articles to Endnote as the articles are used. At a minimum, this technique will ensure a central repository to search out key information. Last, if the student is conducting qualitative research, the student may want to consider contracting a transcription service. Rob tried the free software options and found them inadequate. The service Rob used was GMR Transcription (www. gmrtranscription.com). There are many services and prices vary. Students should conduct research before selecting a service.

\section{Check-in}

Faculty are very accessible. Rob used Skype, desktop sharing, phone calls and in-person meetings to get extra help as he worked through critical decision points. In addition to saving time, checking in is critical to ensure academic rigor as the student applies new skills. Checking-in is also an opportunity for bi-directional learning. It truth the academics are just as curious about the students as the students are about them. DBA students have a wealth of "real world" knowledge to share on even the first day of class.

\section{Conclusions / Lessons Learned}

There are many paths through a DBA journey and no two paths are likely to be identical. The case describes the journey of a life-long learner who combined his work with scholarly efforts to maximize his most precious resource, time. The journey followed by this business leader is not appropriate for every student, but there are elements of the experiences which should be considered by all DBA students. Particular items of note include:

- Make time to think

- When it's time to write, write 
- Keep up with Endnote and your literature survey

- Use publication templates for research papers, then complete them in the publication courses

- Use end of course projects to advance research

- It is your education. The DBA program is not fragile. You can't break it or do it wrong.

When asked if there was one piece of advice or mindset that enabled his journey, Rob shared, "Find a way to advance your research / dissertation project in every class. The result is that the number of faculty on

your dissertation project essentially becomes every professor that you have during the first two years of your program--that's leverage."

\section{References}

Creswell, J. W. (2012). Qualitative inquiry and research design: Choosing among five approaches. London: Sage Publications.

Hinkin, T. R. (1998). A brief tutorial on the development of measures for use in survey questionnaires. Organizational Research Methods, 1(1), 104-121. Retrieved from http://journals.sagepub.com/doi/ abs/10.1177/109442819800100106

\begin{tabular}{|c|c|c|}
\hline Issues & Primary Suggestions & Secondary Suggestions \\
\hline $\begin{array}{l}\text { Be real about } \\
\text { time }\end{array}$ & Make time to think & $\begin{array}{l}\text { Make time to work } \\
\text { Recognize something is going to give }\end{array}$ \\
\hline Topic selection & Pick a topic early & Pick topic related to work \\
\hline Be creative & Ideate and create with paper and pen & $\begin{array}{l}\text { Be prepared to record ideas } \\
\text { when they occur }\end{array}$ \\
\hline Plan & $\begin{array}{l}\text { Leverage the coursework to map a jour- } \\
\text { ney through your interest area }\end{array}$ & $\begin{array}{l}\text { Write papers to explore different } \\
\text { perspectives of research topic }\end{array}$ \\
\hline Get work done & When it's time to write, write & Keep working during the breaks \\
\hline Use the tools & $\begin{array}{l}\text { Write up research using publication } \\
\text { templates, simply turn in appropriate } \\
\text { sections for the write up }\end{array}$ & $\begin{array}{l}\text { Edit research for subsequent } \\
\text { publication courses }\end{array}$ \\
\hline Use the tools & $\begin{array}{l}\text { Create a folder for each class using cloud } \\
\text { storage (e.g., OneDrive, Dropbox) and } \\
\text { save incremental copies of files including } \\
\text { raw data. }\end{array}$ & $\begin{array}{l}\text { Configure Endnote to use cloud } \\
\text { storage (e.g. OneDrive, Drop- } \\
\text { box) }\end{array}$ \\
\hline Stay current & Keep literature summary current & Record the articles in Endnote \\
\hline Stay current & $\begin{array}{l}\text { Make note of search parameters when } \\
\text { researching }\end{array}$ & $\begin{array}{l}\text { Consider hiring a transcription } \\
\text { service to transcribe interviews }\end{array}$ \\
\hline Check-in & Perform a reality check--ask for guidance & \\
\hline
\end{tabular}

\section{Author}

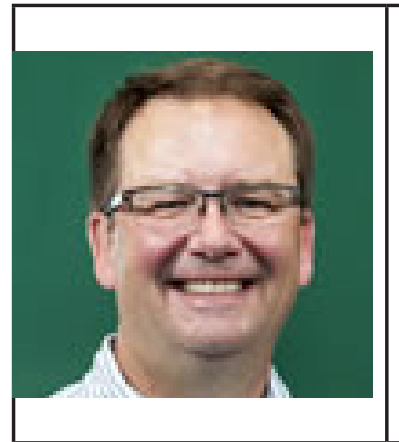

Rob Hammond joined Syniverse in 2013 and has more than 28 years of global leadership experience in enterprise strategy, product management, sales and engineering, with a special focus in mobile and enterprise applications. As Senior Director of Mobile Engagement, Rob is one of the leaders in Syniverse's Enterprise and Intelligence Solutions, the business unit that enables brands and mobile service providers to better engage mobile users. Prior to Syniverse, he served in leadership roles for several of the world's largest mobile and technology companies, including Microsoft, Sprint and Motorola. Rob is currently a doctoral candidate at the Muma College of Business, University of South Florida, with expected graduation in 2017. He also holds a Master of Business Administration, a Master of Science in Engineering, and a Bachelor of Science in Electrical Engineering. 


\section{Exhibit 1: Description of USF DBA program}

\section{What is a DBA?}

The Doctor of Business Administration degree is the original degree intended to qualify faculty members to perform research and teach at business schools. Over the past five years however, a new type of executive doctoral program has started to appear at AACSB-accredited institutions. The new DBA programs, such as the one USF offers, are designed for working professionals and tend to be pursued for different reasons.

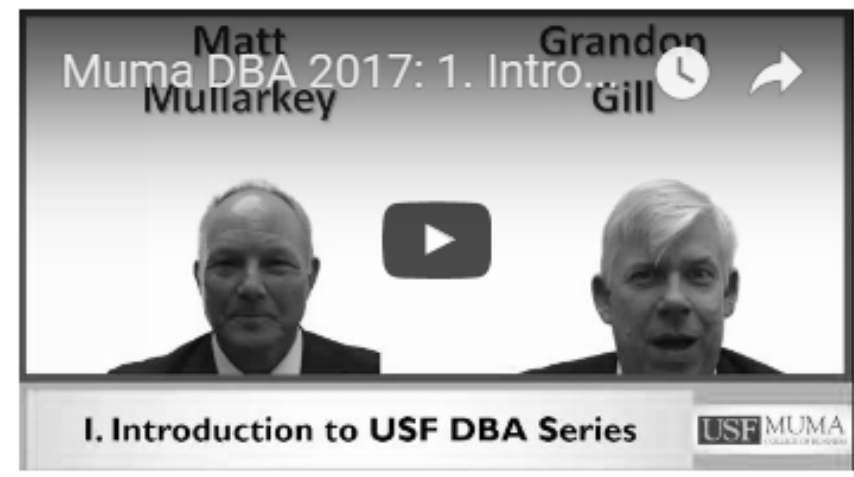

EDBA Council

The Doctor of Business Administration program offered by the USF Muma College of Business provides graduates with the skills needed to conduct rigorous research with the objective of applying the findings to real-world decision-making in industry and government. The program provides intellectual growth as students work closely with faculty in seminars, research projects, and other assignments that develop their research skills and ability to communicate their findings to a broad audience of both practitioners and researchers. It also offers students the opportunity to develop a portfolio of skills that, when combined with the extensive experience that students bring into the program, uniquely qualifies them to serve in clinical faculty positions.

The curriculum is designed to build upon the breadth of business understanding that students have previously achieved as successful executives. This is achieved by offering substantive coverage of a broad variety of qualitative and quantitative research techniques and by allowing students the flexibility to focus more deeply on personal areas of interest during their dissertation. The degree conferred is a

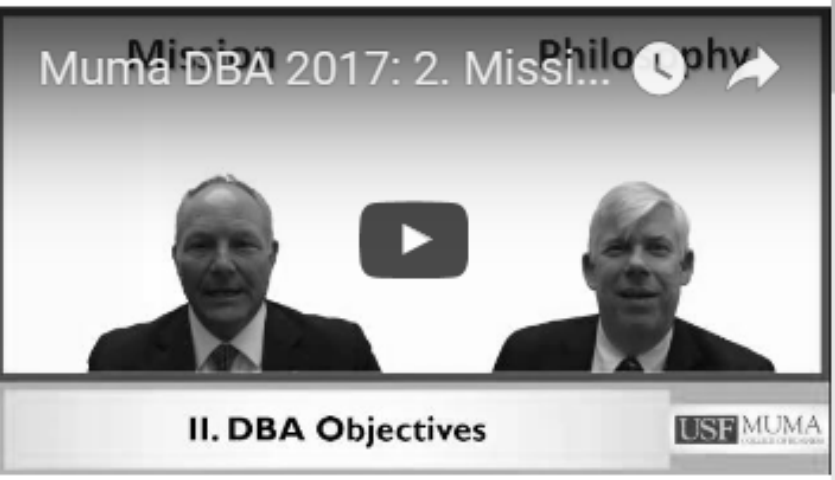
Doctor of Business Administration, a terminal degree so-named to differentiate it from the $\mathrm{PhD}$ degree that specifically focuses on preparing students for an academic research career within a specific discipline.

Source: http://www.usf.edu/business/graduate/dba/program/ 


\section{Exhibit 2: USF DBA Video From YouTube}

- Introduction

- Program Objectives

- Program Structure \& Costs

- Admissions Requirements

- Program Requirements

- Course Types

- Applying to the Program

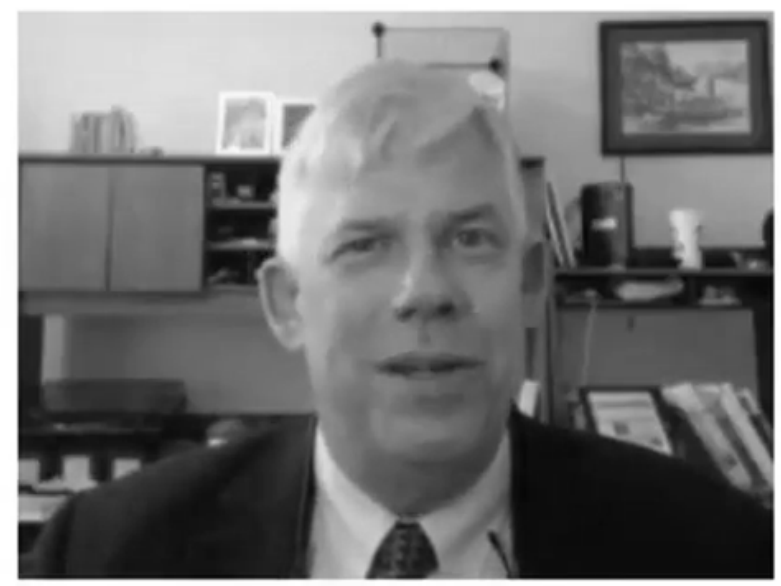

\section{Introduction to USF DBA Series}

Source: https://www.youtube.com/watch?v=yQPAsdXi4v0

\section{Exhibit 3: USF DBA Curriculum}

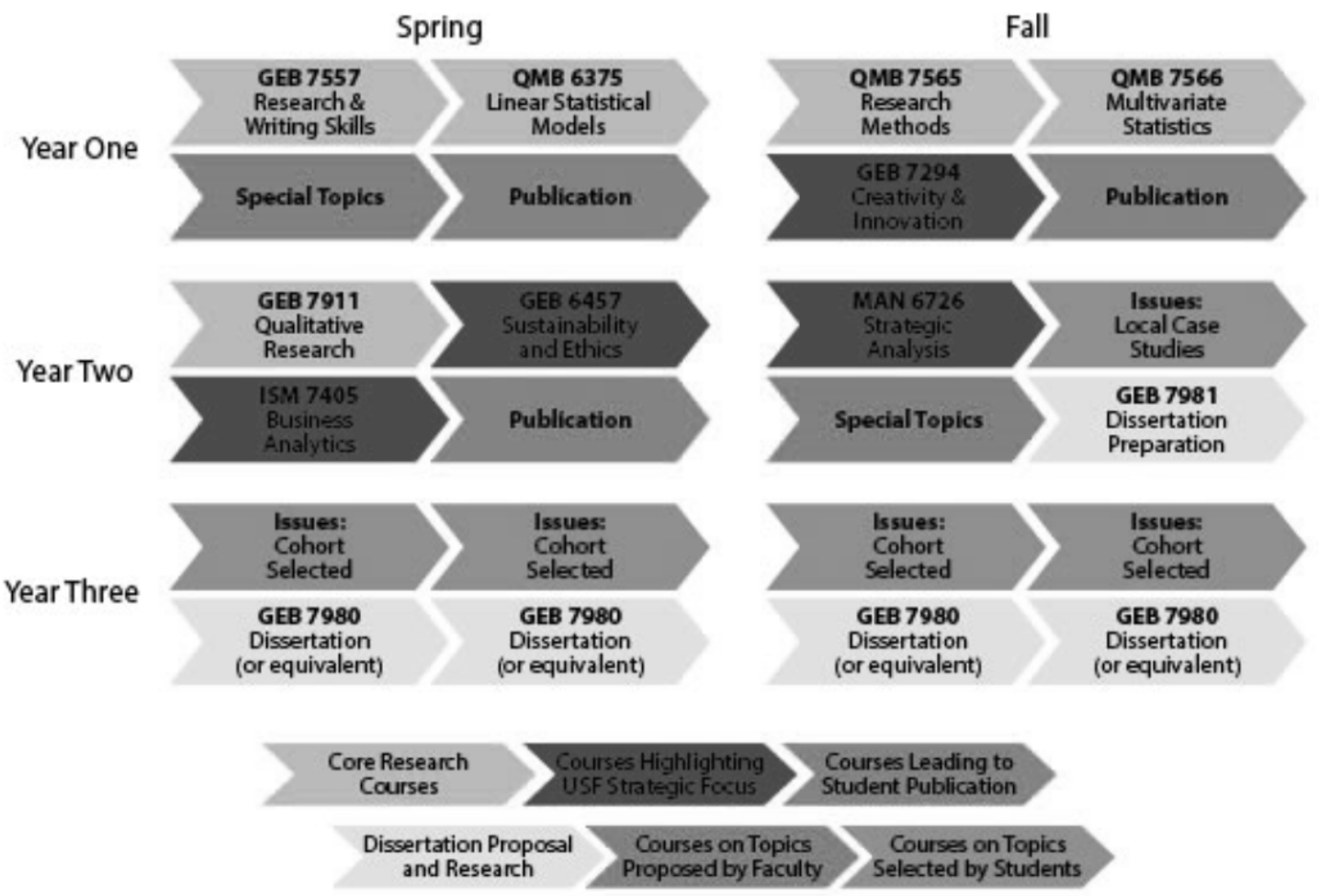

Source: http://www.usf.edu/business/graduate/dba/curriculum/ 


\section{Exhibit 4: DBA Program Year 1 and Year 2 Coursework}

\section{Spring Semester}

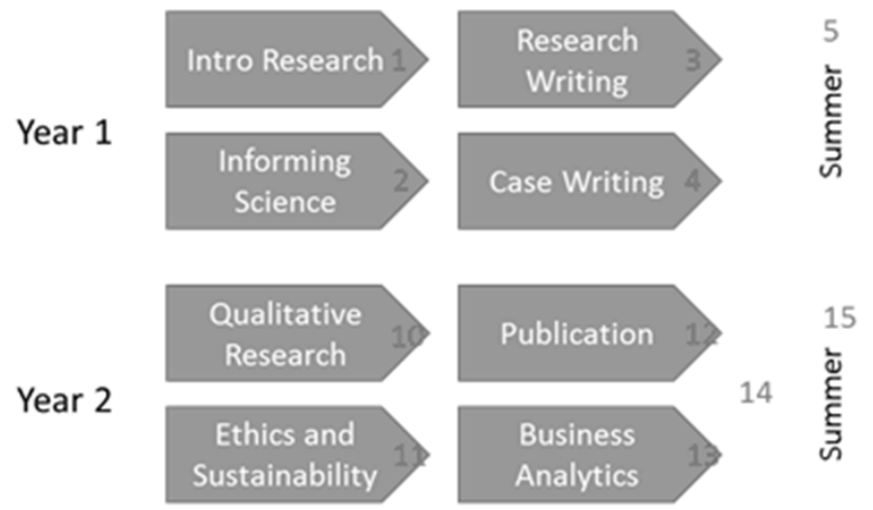

Fall Semester

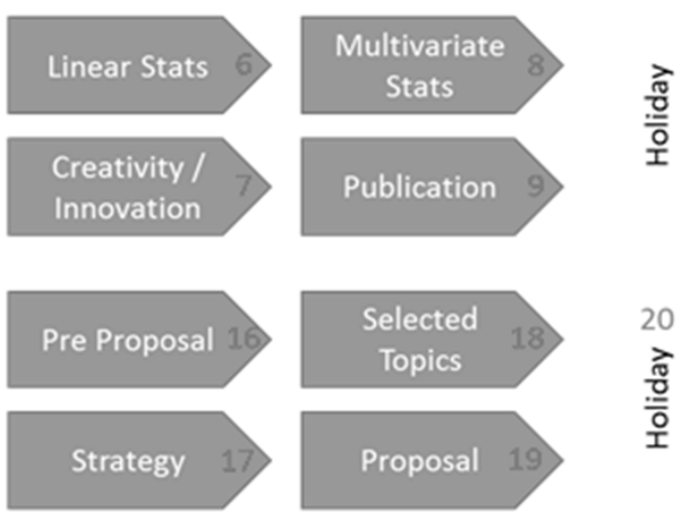

Source: Developed by case writer

\section{Exhibit 5: Chronology of Activities for Quantitative Research}

\begin{tabular}{|c|c|c|}
\hline Reference & Course & Activity \\
\hline 1 & Introduction to Research & Refining Problem Domain \\
\hline 2 & Informing Science & New Theories \\
\hline 3 & Research Writing & Refining Problem Domain \\
\hline 4 & Case Writing & Writing about problem domain \\
\hline 5 & NA - Summer & $\begin{array}{l}\text { Create survey instrument, conduct first } \\
\text { surveys }\end{array}$ \\
\hline 6 & Linear Statistics & Conduct statistical analysis \\
\hline 7 & Creativity / Innovation & Self-discovery \\
\hline 8 & Multivariate Statistics & Conduct statistical analysis \\
\hline 9 & Publication & Publish findings from first survey \\
\hline 10 & Qualitative Research & Develop model \\
\hline 11 & Law, Ethics and Sustainability & Size market \\
\hline 12 & Publication & $\begin{array}{l}\text { Publish findings from qualitative } \\
\text { research }\end{array}$ \\
\hline 13 & Business Analytics & Write chapter for book \\
\hline 14 & Qualifying Examination & Organize research \\
\hline 15 & NA - Summer & $\begin{array}{l}\text { Confirmatory research on complexity, } \\
\text { Confirmatory research on Innovation }\end{array}$ \\
\hline 16 & Strategy & Map models to theories \\
\hline 17 & Strategic Climates & Adapt climate embedding mechanisms \\
\hline 18 & Life in Academia & Develop course \\
\hline 19 & Dissertation Preparation & Work on book draft \\
\hline 20 & Holiday Break & Work on book draft \\
\hline
\end{tabular}

Source: Developed by case writer 


\section{Exhibit 6: Sales Type Survey Development}

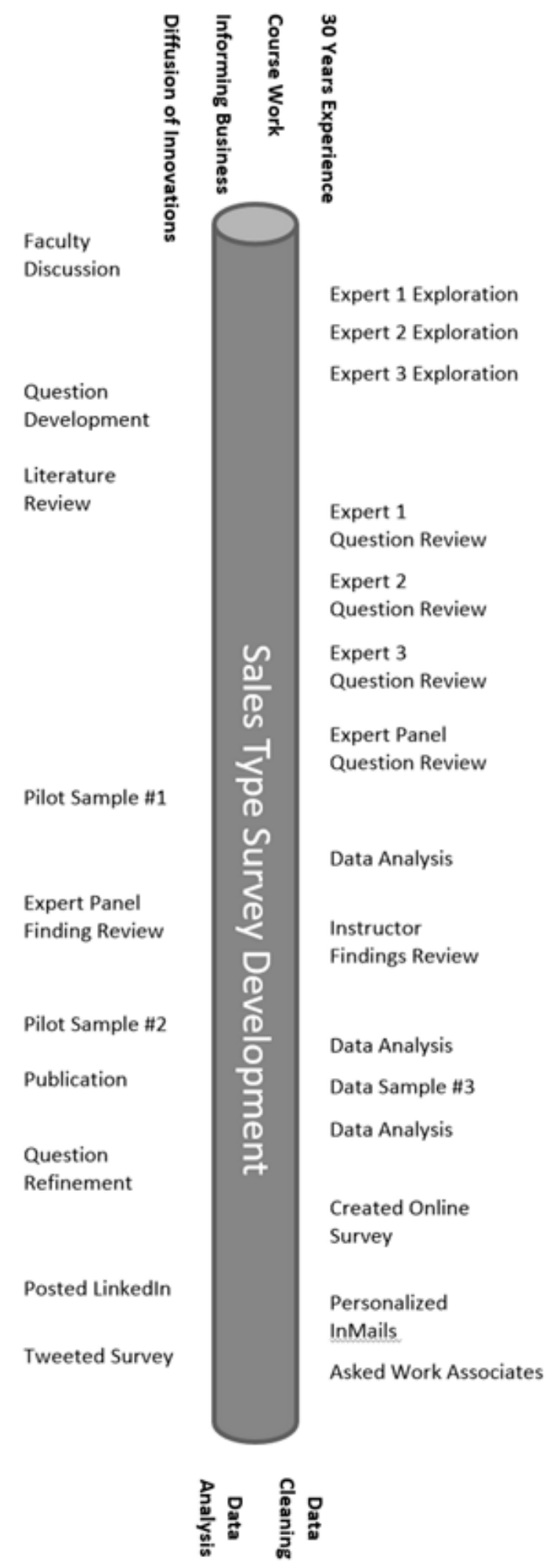

Source: Developed by case writer 


\section{Exhibit 7: Dates and Activities Ass, ciated with “Today, I Fired My}

\begin{tabular}{|l|c|}
\hline \multicolumn{1}{|c|}{ Activity } & Date \\
\hline Practice & 1986 - 2015 \\
\hline Informing Science Class & Jan - Apr 2015 \\
\hline Research Methods Class & Jan - Apr 2015 \\
\hline Discussion Case Class & Apr - Ju 2015 \\
\hline Expert Panel Selection & 15-Jul-2015 \\
\hline Expert 1 Interview & 15-Jul-2015 \\
\hline Expert 2 Interview & 16-Jul-2015 \\
\hline Expert 3 Interview & 17-Jul-2015 \\
\hline Literature Review & Jun - Sep 2015 \\
\hline Question Development & Sep 2015 \\
\hline Expert 1 Question Review & 8-Sep-2015 \\
\hline Expert 2 Question Review & 10-Sep-2015 \\
\hline Expert 3 Question Review & 9-Sep-2015 \\
\hline Panel Question Review & 11-Sep-2015 \\
\hline Sample 1 & Sep 1 \& 2, 2015 \\
\hline Data Analysis & 1-Sep-2015 \\
\hline Panel Results Meeting & 12-Oct-2015 \\
\hline Instructor Results Meeting & 6-Oct-2015 \\
\hline Sample 2 & Oct 13 \& 14, 2015 \\
\hline Data Analysis & 31-Oct-2015 \\
\hline Paper Development & Sep - Dec 2015* \\
\hline Paper Submitted for Review & 4-Dec 2015* \\
\hline
\end{tabular}

* Estimated Dates 


\section{Exhibit 8: Activities Associated with Quantitative Research for an Existing Survey}

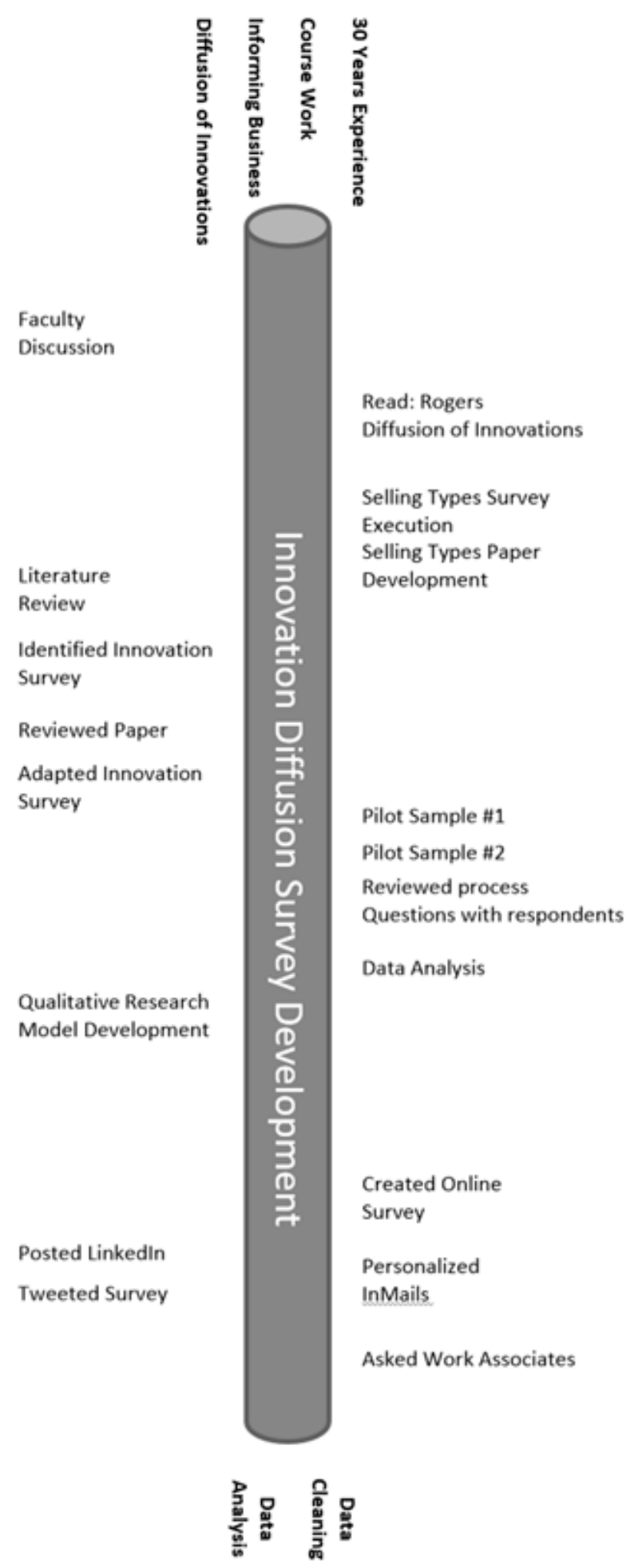

Source: Developed by case writer 


\section{Exhibit 9: Qualitative Research Process Flow}

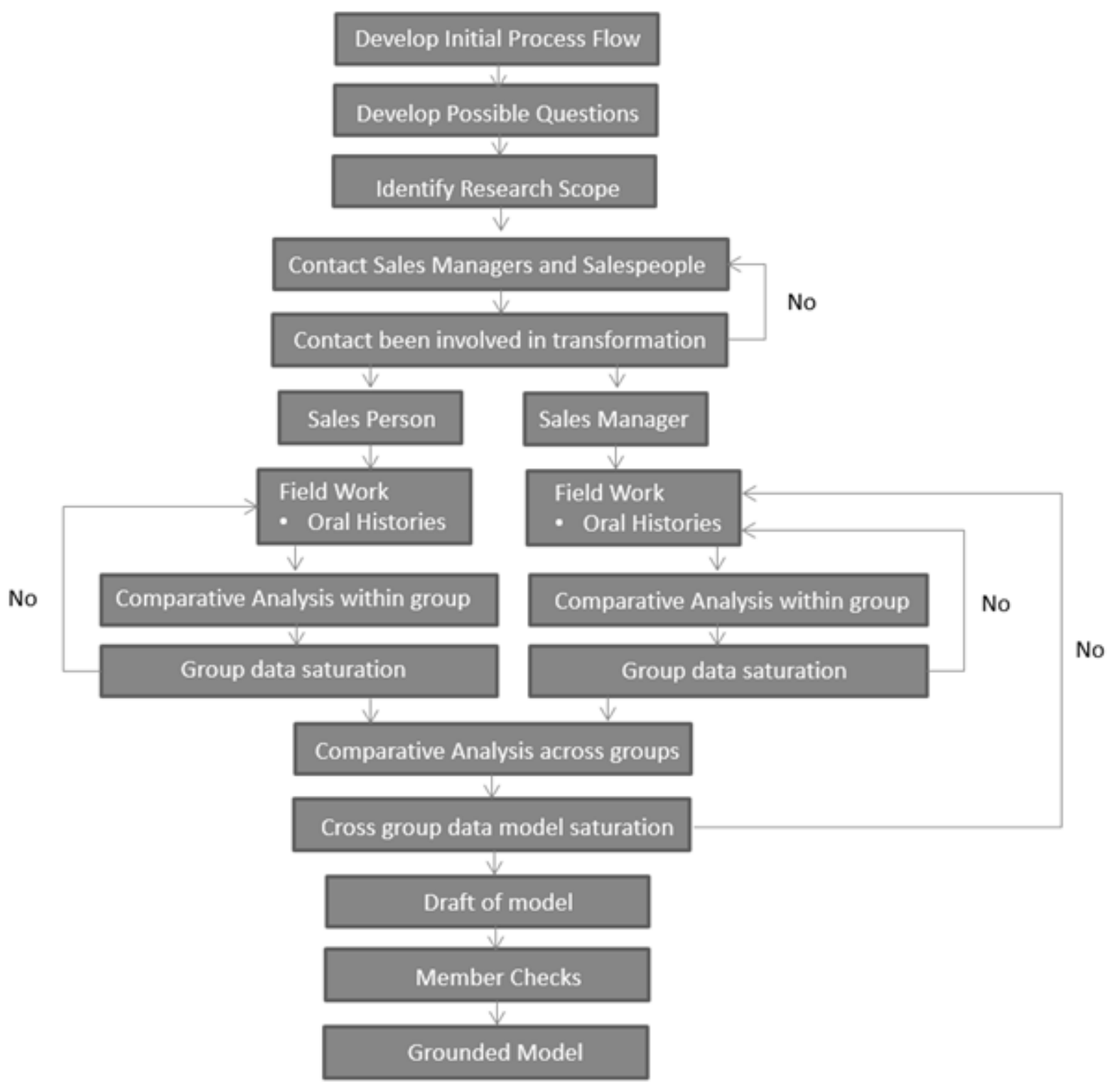

Source: Developed by case writer 


\section{Exhibit 10: Schedule of Activities for Qualitative Grounded Theory
Research}

\begin{tabular}{|l|c|}
\hline \multicolumn{1}{|c|}{ Activity } & Date \\
\hline Literature Survey & Sep 2015 - 2016 \\
\hline Other Informing Research & Feb 2015 - Jun 2016 \\
\hline Study Design & Feb 2016 \\
\hline Question Development & Feb 2016 - Mar 2016 \\
\hline Informant Recruiting & Apr 2016 \\
\hline Phase 1 Interviews & Apr 2016 \\
\hline Coding & Apr 2016 \\
\hline Model Development & Apr 2016 \\
\hline Model Refinement & May 2016 \\
\hline Confirmatory Interviews & Jun 2016 \\
\hline
\end{tabular}

Source: Developed by case writer

\section{Exhibit 11: Sample of Coding from Qualitative Grounded Theory}

\begin{tabular}{|c|c|c|c|c|c|c|c|c|c|c|}
\hline & \multicolumn{10}{|c|}{ Informants } \\
\hline & \multicolumn{3}{|c|}{ Informing Model } & \multicolumn{4}{|c|}{ Confirming Model } & \multicolumn{2}{|c|}{ Informing Model } & \multirow{2}{*}{$\begin{array}{c}\begin{array}{c}\text { Confirming } \\
\text { Model }\end{array} \\
\text { SP } 3 \\
\end{array}$} \\
\hline & SM 1 & SM 2 & SM 3 & SM 4 & SM 5 & SM 6 & SM 7 & SP 1 & SP 2 & \\
\hline \multicolumn{11}{|l|}{ Cause of Change } \\
\hline Competition & $\mathrm{x}$ & & & & $\mathrm{x}$ & & & $\mathrm{x}$ & $x$ & $\mathrm{x}$ \\
\hline Merger & & $x$ & & & & & & & & \\
\hline Marketplace / Business / & $x$ & & & $x$ & $\mathrm{x}$ & & $x$ & $\mathrm{x}$ & $x$ & $x$ \\
\hline Unethical behavior in & & & & & & $x$ & & & & \\
\hline \begin{tabular}{|l} 
High turnover \\
\end{tabular} & & & & & & $x$ & & & & \\
\hline \multicolumn{11}{|l|}{ Warning Signs } \\
\hline Pipeline & $x$ & & & $x$ & & & & & & $\mathrm{x}$ \\
\hline Not selling new product & $x$ & & & & & & & & & \\
\hline Confusion & $x$ & & & & & & & & & \\
\hline \begin{tabular}{|l|} 
Sales Person Interactions \\
\end{tabular} & & $x$ & & & & & & & & \\
\hline \begin{tabular}{|l|} 
Revenue down \\
\end{tabular} & & & $\mathrm{x}$ & $x$ & $\mathrm{x}$ & & & & & $\mathrm{x}$ \\
\hline Tenure / High turnover & & & & & & $x$ & & & & \\
\hline \multicolumn{11}{|l|}{ Symptoms } \\
\hline Pipeline & 5 & & & 5 & $x$ & 5 & & & & 5 \\
\hline $\begin{array}{l}\text { Lower Revenue } \\
\end{array}$ & 2.5 & & 5 & & $x$ & & & 5 & 5 & 5 \\
\hline \begin{tabular}{|l} 
Product Specs \\
\end{tabular} & 3 & & 2 & & & & & 5 & & \\
\hline Margin Pressure & & & 3 & & & & & & 5 & 5 \\
\hline Too Much Product & & & 4 & & & & & & & \\
\hline New Competitors & & & & 2.5 & $x$ & & & & 3 & \\
\hline Old sellers need to & & & & & & & & & 3 & \\
\hline MBO & & & & 4 & & & & & & \\
\hline Not doing right things to & & & & & & 5 & & & & \\
\hline People not making & & & & & & 5 & & & & \\
\hline Tenure & & & & & & 5 & & & & \\
\hline \multicolumn{11}{|l|}{ Pay } \\
\hline Pay not clear selling & & & & & & & & & & 5 \\
\hline Keep doing what have & & & & & & & $x$ & & & \\
\hline \multicolumn{11}{|l|}{ Tactics } \\
\hline Coaching 1:1 & 5 & 5 & & 3 & & $x$ & 3 & 4 & 3 & 4 \\
\hline \begin{tabular}{|l} 
Role Plays \\
\end{tabular} & & 4 & 1 & & & & 4 & & & \\
\hline Tests & & 3 & & & & & $\mathrm{x}$ & & & \\
\hline SWAT Team & 4 & & & & & & & & & \\
\hline \begin{tabular}{|l|} 
Compensation Plan \\
\end{tabular} & 3 & & & $x$ & & $x$ & $\mathrm{x}$ & & 4 & 5 \\
\hline Executive Committee & 2 & & & & & & & & & \\
\hline \begin{tabular}{|l|} 
Webinars \\
\end{tabular} & & & 2 & & & & & & & \\
\hline Went on sales calls & & & 5 & 4 & $x$ & $x$ & 3 & & & 5 \\
\hline Published content & & & 2 & & $x$ & & & & & \\
\hline \begin{tabular}{|l|} 
Provided Sales collateral \\
\end{tabular} & & & 2 & & & & & & & \\
\hline Added special incentive & & & 1 & & & & & & & \\
\hline Directive from CXO & & & & & & & & 5 & & \\
\hline Training & & & & & $\mathrm{x}$ & & $5 *$ & 3.5 & & \\
\hline
\end{tabular}

Source: Developed by case writer 


\section{Exhibit 12: Sample of Cumulative Literature Review}

\begin{tabular}{|c|c|c|c|c|c|}
\hline Type & Topic & Findings & Citing & Impact & Application to Research \\
\hline Paper & $\begin{array}{l}\text { Theory } \\
\text { Strategic Implemenation } \\
\text { Climate } \\
\text { Transformational } \\
\text { Leadership }\end{array}$ & $\begin{array}{l}\text { Strategic Implementation Climate and } \\
\text { Transformational Leadership can enhance } \\
\text { adoption of Evidence Based healthcare } \\
\text { Practices (EBP)s. }\end{array}$ & $\begin{array}{l}\text { Aarons, G. A., Farahnak, L. R., Ehrhart, } \\
\text { M. G., \& Sklar, M. (2014). Aligning } \\
\text { Leadership Across Systems and } \\
\text { Organizations to Develop Strategic } \\
\text { Climate to for Evidence-Based Practice } \\
\text { Implementation. Annual review of public } \\
\text { health, 35, 255. }\end{array}$ & $\begin{array}{l}\text { Paper lists Edgar Schein's "climate } \\
\text { embedding mechanisms". } 6 \text { primary and } 6 \\
\text { secondary mechanisms along with } \\
\text { examples for healthcare. } \\
\text { Paper includes definition of } \\
\text { transformational leadership and examples } \\
\text { applied to the strategic implementation } \\
\text { climate. }\end{array}$ & $\begin{array}{l}\text { Strategic Implmentation Climate and Transformational } \\
\text { Leadership provide theory explanation of the leadership } \\
\text { and activities that were found to impact sales behavior } \\
\text { adoption. } \\
\text { Healthcare delivery and sales have many parallels. }\end{array}$ \\
\hline Paper & $\begin{array}{l}\text { Theory } \\
\text { Innovation Diffusion }\end{array}$ & $\begin{array}{l}\text { 1) "many innovations, whether they be } \\
\text { new disearses, new cures or new } \\
\text { techniques and technologies, diffuse } \\
\text { through social networks linking } \\
\text { individuals or organizations." } \\
\text { 2)" these networks are segemented by } \\
\text { interanlboundaries wh } \\
\text { ich can form at geographic, status, } \\
\text { cultrual, or industry lines." } \\
\text { 3) "these boundearies can limit the } \\
\text { diffusion of innovations, so that } \\
\text { innvoations frequently do not diffuse to } \\
\text { all potential adopters" }\end{array}$ & $\begin{array}{l}\text { Abrahamson, E., \& Rosenkopf, L. } \\
\text { (1997). Social network effects on the } \\
\text { extent of innovation diffusion: A } \\
\text { computer simulation. Organization } \\
\text { science, 8(3), 289-309. }\end{array}$ & $\begin{array}{l}\text { "Theories of innovation diffusion no longer } \\
\text { focus exclusively on explaining the rate at } \\
\text { which innovations diffuse or the sequence } \\
\text { in which they are adopted. They also focus } \\
\text { on explaining why certain innovations } \\
\text { diffusie extensively." }\end{array}$ & $\begin{array}{l}\text { Broadened understanding of the applicability of } \\
\text { innovation diffusion to research topics. Concept of } \\
\text { boundaries contributes to idea of differences of people } \\
\text { having different threasholds of hygiene variables. }\end{array}$ \\
\hline
\end{tabular}

Source: Developed by case writer

\section{Exhibit 13: Sample of raw sample data highlighted with cleaning is- sues}

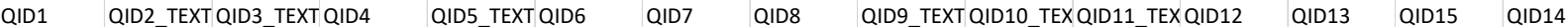
Q1 - What Q2 - At the Q3 - How nQ4 - In whi Q5 - How nQ6 - How nQ7 - How n Q8 - Does , Q9 - How nQ10 - How Q11 - Wha Q12 - I am Q13 - My [Q15 - My LQ14 - am

\begin{tabular}{|c|c|c|c|c|c|c|c|c|c|c|c|c|c|}
\hline 1 & 0 & 12 & 1 & 1 & 3 & 12 & 1 & 6 & 3 Keep bette & 4 & 1 & 1 & 1 \\
\hline 1 & 1 & 1 & 1 & 2 & 2 & 9 & 1 & 6 & 3 Start the $\mathrm{RI}$ & 4 & 1 & 2 & 1 \\
\hline 1 & 3 & 3 & \multicolumn{2}{|c|}{1 None } & 3 & 6 & 2 & 6 & 4 Read More & 3 & 2 & 2 & 1 \\
\hline $112+$ & \multicolumn{2}{|c|}{$20+$} & 2 & 3 & 2 & 3 & 3 & 6 all & Refine My I & 3 & 1 & & 1 \\
\hline 1 & 15 & 15 & 2 & 2 & 2 & 12 & 1 & 5 & 8 Decrease $\mathrm{r}$ & 2 & 1 & 1 & 1 \\
\hline 1 & 14 & 14 & 2 & 2.5 & 1 & 4 & 3 & 6 & 5 not sure & 2 & 1 & 2 & 1 \\
\hline 1 & 4 & 9 & 1 & 4 & 2 & 12 & 3 & 6 & 6 Work part 1 & 1 & 2 & 2 & 2 \\
\hline 1 & 0 & 0 & 1 & 2 & 1 & 5 & 2 & 6 & 2 Be Unempl & 1 & 3 & 3 & 2 \\
\hline 1 & 2012 & 2012 & \multicolumn{2}{|c|}{1 None } & 4 & 8 & 1 & 6 & 3 I think I am & 3 & 1 & 1 & 1 \\
\hline 1 & 0 & 1 & 1 & 2 & 2 & 6 & 1 & 6 & 6 have an int & 2 & 1 & 1 & 1 \\
\hline 1 & 15 & 15 & 1 & 2 & 2 & 7 & 3 & 10 & 9 Think of co & 1 & 2 & 2 & 1 \\
\hline \multirow{2}{*}{\multicolumn{3}{|c|}{$\begin{array}{l}15 \text { years } 5 \text { years } \\
1 \text { less than ol } 6 \text { months }\end{array}$}} & 1 & 0 & 3 & 12 & 1 & 6 & 5 maintain a & 3 & 1 & 1 & 1 \\
\hline & & & \multicolumn{2}{|c|}{2 three } & 2 & 12 & 1 six & six & more one $c$ & 1 & 1 & 1 & 1 \\
\hline 1 & 5 & 5 & 1 & 3 & 2 & 12 & 1 & 6 & 3 stay with si & 1 & 2 & 2 & 1 \\
\hline 1 & 10 & 10 & 2 & 3 & 2 & 6 & 1 & 6 & 6 Go to more & 2 & 1 & 1 & 2 \\
\hline 1 & 12 & 12 & 1 & 0 & 3 & 12 & 1 & 6 & 5 Read more & 3 & 2 & 2 & 1 \\
\hline 1 & 12 & 12 & & & 3 & 7 & 3 & 10 & 8 find out wr & 1 & 4 & 4 & - \\
\hline
\end{tabular}

Source: Developed by case writer 


\section{Exhibit 14: Year 1 student regression - dependent variable anxiety about dissertation}

\begin{tabular}{|l|r|r|r|r|}
\hline & coefficient & std.error & t.value & p.value \\
\hline Years.since.academic.course & 0.029 & 0.025 & 1.172 & 0.271 \\
\hline Year.selected.topic & -0.576 & 0.348 & -1.656 & 0.132 \\
\hline How.much.complete.year.1 & 0.325 & 0.230 & 1.414 & 0.191 \\
\hline Use.Quantitative.Analysis & -0.177 & 0.207 & -0.857 & 0.414 \\
\hline Course.Completed & 0.138 & 0.086 & 1.607 & 0.142 \\
\hline Courses.that.relate & -0.267 & 0.065 & -4.125 & $0.003 * *$ \\
\hline Unique.insights & -0.506 & 0.223 & -2.265 & $0.050 *$ \\
\hline Access.to.people.and.data & 0.292 & 0.278 & 1.049 & 0.322 \\
\hline Better.at.job & 0.397 & 0.310 & 1.282 & 0.232 \\
\hline Data.will.be.hardest & 0.233 & 0.175 & 1.326 & 0.218 \\
\hline Pursue.a.new.career & 0.250 & 0.157 & 1.593 & 0.146 \\
\hline Statistical.analysis.hardest & 0.177 & 0.167 & 1.064 & 0.315 \\
\hline Struggled.with.statistics & 0.486 & 0.164 & 2.973 & 0.016 \\
\hline Confident.will.finish & -0.380 & 0.210 & -1.810 & 0.104 \\
\hline Make.me.a.thought.leader & -0.511 & 0.244 & -2.090 & 0.066. \\
\hline Used.each.course.to.propel & 0.396 & 0.184 & 2.154 & 0.060. \\
\hline
\end{tabular}

\section{Exhibit 15: Year 2 student regression - dependent variable anxiety about dissertation}

\begin{tabular}{|l|r|r|r|l|l|}
\hline & coefficient & std.error & t.value & \multicolumn{1}{l|}{ p.value } \\
\hline How.much.complete.year.2 & 0.4017 & 0.0645 & 6.2319 & $0.0004 * *$ \\
\hline Use.Quantitative.Analysis & 0.9224 & 0.2544 & 3.6257 & $0.0084 * *$ \\
\hline Unique.insights & -1.2229 & 0.1813 & -6.7470 & $0.0003^{* * *}$ \\
\hline Passionate.about.topic & 1.0663 & 0.2774 & 3.8445 & $0.0063^{* *}$ \\
\hline Statistical.analvsis.hardest & 0.5029 & 0.1442 & 3.4874 & $0.0102 *$ \\
\hline
\end{tabular}

\section{Exhibit 16: Combined year 1 and year 2 DBA student regression - de- pendent variable anxiety about dissertation}

\begin{tabular}{|l|r|r|r|l|l|}
\hline & coefficient & std.error & t.value & p.value \\
\hline DBA.program.year & -1.716 & 0.888 & -1.933 & 0.064 \\
\hline Years.since.graduation & -0.024 & 0.013 & -1.943 & 0.062 \\
\hline How.much.complete.year.1 & 0.329 & 0.187 & 1.759 & 0.090 \\
\hline How.much.complete.year.2 & 0.270 & 0.114 & 2.366 & $0.025^{*}$ \\
\hline Use.Quantitative.Analysis & -0.291 & 0.179 & -1.620 & 0.117 \\
\hline Course.Completed & 0.126 & 0.077 & 1.636 & 0.113 \\
\hline Courses.that.relate & -0.124 & 0.043 & -2.896 & $0.007^{* *}$ \\
\hline Unique.insights & -0.452 & 0.163 & -2.779 & $0.010^{* *}$ \\
\hline Statistical.analysis.hardest & 0.557 & 0.123 & 4.522 & $0.000^{* * *}$ \\
\hline Naturally.flows.from.coursework & -0.466 & 0.169 & -2.749 & $0.011^{*}$ \\
\hline Confident.will.finish & -0.255 & 0.136 & -1.872 & 0.072 \\
\hline Used.each.course.to.propel & 0.394 & 0.170 & 2.320 & $0.022^{*}$ \\
\hline
\end{tabular}

$\mathrm{R}^{2} .764$, adjusted $\mathrm{R}^{2} .659$

Exhibits 14-16 developed by case writer 


\section{Appendix
Survey of Yearl and Year 2 DBA
Students}

\section{Introduction}

As part of the initial case presentation, an online survey was conducted of Year 1 and Year 2 DBA students in the Muma College of Business, University of South Florida DBA program. The goal of the survey was to explore the sources of anxiety related to the end of program dissertation and assess the student's views on the usefulness and degree to which they used the suggestions presented in the case. DBA program year was included in the survey to facilitate comparison of results between year 1 and year 2 students. The comparison between the student years suggests that there is an opportunity to inform year 1 students of future needs and thereby avoid unnecessary stress, "don't worry this is normal." The survey, associated data and analysis provide relatable exemplars of quantitative analysis for students beginning their DBA journey.

\section{Exploratory Research Question}

There are several exploratory research questions within the survey. The first question was to determine whether students agreed with the suggestions presented in the case. The second area of inquiry was to determine if students in year 1 had different perspectives of the suggestions from their year 2 counterparts. The third and final question explored the sources of anxiety associated with the DBA program final project/dissertation.

\section{Hypothesis}

Embedded within the survey were multiple hypotheses regarding the source of dissertation anxiety and the value students placed on the suggestions presented in the case. Given the goal of the survey was exploratory, the hypotheses are broad and cover multiple dimensions.

The null hypothesis for the research was:

- $\mathrm{H}_{0}$ : The suggestions presented in the case are not useful to students.

Additional hypotheses included:

- $\mathrm{H}_{1}$ : There is no difference between year 1 and year 2 DBA students with regard to how much they used the suggestions presented in the case.

- $\mathrm{H}_{2}$ : There is no difference between year 1 and year 2 DBA students with regard to the usefulness of the suggestions presented in the case.

- $\mathrm{H}_{3}$ : Statistics is a significant source of anxi- ety for DBA students.

- $\mathrm{H}_{4}$ : Obtaining data for the dissertation is a source of anxiety for DBA students.

- $\mathrm{H}_{5}$ : Students who leverage the coursework and structure of the DBA program have less anxiety about the dissertation.

- $\mathrm{H}_{6}$ : Intrinsic and Extrinsic Motivation reduce the anxiety associated with the dissertation.

\section{Method}

Survey questions were developed by the case writer and reviewed by the DBA Program Director. Feedback from the Program Director was incorporated into the survey structure and associated edits were made to the questions. The original plan for the survey was to administer the survey as a two-sided paper handout. After discussing the survey with the DBA Academic Director, the case writer decided to deliver the survey as an on-line survey, as it would reduce data entry and provide a better learning opportunity for the year 1 and year 2 students.

The survey was posted to the university electronic course administration site (Canvas) and the DBA Program Administer requested that the year 1 students complete the survey. The survey was provided to the year 1 students before they read the associated case. The case writer asked the year 2 students to complete the survey the next morning at the start of class. Although the year 2 students did not review the case, the case writer was a member of the year 2 cohort and as such, the year 2 students had a general familiarity of the circumstances associated with the case.

The survey data was downloaded to Excel. Text entries for numeric values were changed to numeric (e.g. six changed to 6) and incomplete responses were deleted. Examples of the data cleaning process are highlighted in Exhibit 13. Descriptive statistics were calculated in Excel. The descriptive statistics included maximum, minimum, range, average and standard deviations for the year 1 student sample, year 2 student sample and the two student groups combined. Differences between the year 2 and year 1 groups were also calculated. A statistics package (Radiant) was used to calculate linear regressions for year 1 students, year 2 students and the combined year 1 and year 2 students using anxiety about the dissertation as the dependent variable.

\section{Findings}

A total of 40 students completed the survey, 26 year 1 DBA students and 14 year 2 DBA students. The data validates that the suggestions presented in case provide value to students. Of the 19 suggestions presented in the case, year 1 DBA students found only one suggestion to be not useful and year 2 DBA students found no suggestion to be not useful and only 
1 suggestion to be neutral.

- Year 1 DBA students on average responded that "Consider using a transcription service" was not useful.

- Year 2 DBA students on average responded that "Keep working during the breaks" was neutral.

The highest ranked suggestion for year 1 DBA students had an average ranking of 1.5. The suggestion was:

- "Make note of search parameters when researching."

Three suggestions were ranked the highest (1.71) for year 2 DBA students. The three suggestions were:

- "Make time to think."

- "Use coursework to map a journey through your interest area."

- "Be prepared to record ideas when they occur."

Comparisons between the two student groups is enlightening. It has been on average 11.8 years longer since the last academic course for year 2 DBA students and 11.2 years longer since their last graduation. Both groups commented that about $10 \%$ of the dissertation was completed in year 1 of the program and the year 2 DBA students indicated that $30 \%$ to $40 \%$ of the dissertation was completed during year 2 of the DBA program. Year 1 DBA students indicated that $60 \%$ of coursework related to the topic of inquiry and year 2 DBA students responded that $45 \%$ of the coursework applied.

Response difference of |.4| between the two groups are shown in Table 1 below.

Given the differences in the groups, linear regressions were performed on each group separately and on the two groups combined. Anxiety regarding the DBA dissertation was the dependent variable in each regression. Radiant (statistics package) was used with each group. Exhibit 14 presents the year 1 DBA student regression while Exhibit 15 and 16 present the year 2 DBA student and combined student regressions respectively.

\section{Discussion}

The null hypothesis can be rejected on the strength of support for the suggestions presented in the case by both the year 1 and year 2 DBA students. There is also support for the other hypothesis as well. Table 2 below presents the average scores for the student groups for Used and Usefulness. Interestingly while there are some differences across the 19 suggestions, the averages across the groups are similar for both Used and Usefulness. Further, there is a substantial gap between the average scores for Used and Usefulness. The similarity between groups and significant gap suggests that students are not discovering the techniques associated with the suggestions on their own and informing support might add value independent of the year in the program.

Table 2: Average Suggestion score for Used and Usefulness by DBA student year

\begin{tabular}{|l|c|c|}
\cline { 2 - 3 } \multicolumn{1}{c|}{} & \multicolumn{2}{c|}{ Average Suggestion Ranking } \\
\cline { 2 - 3 } \multicolumn{1}{c|}{} & Used & Useful \\
\hline Year 1 Students & 2.7 & 2.0 \\
\hline Year 2 Students & 2.6 & 2.1 \\
\hline
\end{tabular}

An alternative explanation for the gap is that the students did not understand the ideas of Used and Usefulness. With 40 respondents, it is likely that there were differences in understanding and with the relatively small number of samples, further research to confirm the data is warranted.

Regression analyses suggest that statistics is a challenge for both groups separately and for the combined student population as well. There is also evidence to support the hypotheses associated with motivation, coursework and program structure.

It should be noted that the survey sample size is small, particularly for the year 2 DBA student group $(\mathrm{N}=14)$ and that the year 2 DBA cohort included the case author in the cohort. As such, the statistical analysis should be considered directional and ex-

Table 1: Descriptive statistics of Year 1 and Year 2 DBA student survey responses

\begin{tabular}{|l|l|c|c|c|}
\cline { 3 - 5 } \multicolumn{2}{l|}{} & Year 2 & Year 1 & Difference \\
\hline & Q12 - I am feeling a significant amount of anxiety about my dissertation & 2.6 & 2.2 & 0.4 \\
\hline & Q21 - My DBA dissertation flows naturally from the coursework I've already comple... & 2.1 & 2.5 & -0.4 \\
\hline Used & Q45_4 - Leverage the coursework to map a journey through your interest area & 2.4 & 2.8 & -0.4 \\
\hline Used & Q45_16 - Edit research write ups for next publication courses & 2.5 & 3.2 & -0.7 \\
\hline Used & Q45_19 - Consider hiring a transcription service to transcribe interviews & 3.4 & 4.5 & -1.1 \\
\hline Useful & Q46_9 - Make note of search parameters when researching & 2.2 & 1.5 & 0.7 \\
\hline Useful & Q46_11 - Make time to work & 1.9 & 1.4 & 0.5 \\
\hline Useful & Q46_14 - Write papers to explore different perspectives of research topics & 2.3 & 1.8 & 0.5 \\
\hline Useful & Q46_15 - Keep working during the breaks & 3 & 2.2 & 0.8 \\
\hline Useful & Q46_19 - Consider hiring a transcription service to transcribe interviews & 2.4 & 3.5 & -1.1 \\
\hline
\end{tabular}


ploratory. That said, there is evidence to support the value of the suggestions presented in the case and to suggest areas where additional informing efforts can be targeted.

\section{Further Research}

The case, survey and data analysis suggest multiple avenues for further study. First, the nature of the cohort based program lends itself to longitudinal study. A longitudinal study could examine the changes in attitudes of the cohort across years. Second, it would be instructional to observe the effect of changing the curricula on anxiety and the case suggestions as the DBA program evolves. Also, instructional would be examining the makeup of the cohorts to determine if the changes are related to the stage in the program or uniqueness of the cohort.

Another dimension of research would be to determine if the structure of the Muma College of Business, University of South Florida DBA program is unique related to the case suggestions, or if the findings can be generalized to other DBA programs, executive education, adult learning, or academics in general.

\section{Conclusion}

While it is noted that the data samples were small and limited to a just one DBA program and two cohorts, the 40 DBA students surveyed responded positively to the usefulness of the 19 suggestions presented in the case. Further, analysis shows a persistent significant gap in the reported usefulness of the suggestions and the amount the suggestions were used by both year 1 and year 2 DBA students. These findings when combined present strong support for intervention in the emergent learning process for DBA students.

\section{Review}

This article was accepted under the constructive peer review option. For futher details, see the descriptions at:

http://mumabusinessreview.org/peer-review-options/ 